\title{
The Importance of Using Augmented Reality in the Study of Kubra Al-Yaqiniyyat
}

Mohd Hasrul Shuhari, Mohammed Muneer'deen Olodo Al-Shafi'i, Aman Daima Md. Zain, Wan Hishamudin Wan Jusoh \& Mohd Manawi Mohd Akib

To Link this Article: http://dx.doi.org/10.6007/IJARBSS/v10-i11/8205 DOI:10.6007/IJARBSS/v10-i11/8205

Received: 11 September 2020, Revised: 12 October 2020, Accepted: 15 November 2020

Published Online: 25 November 2020

In-Text Citation: (Shuhari et al., 2020)

To Cite this Article: Shuhari, M. H., Al-Shafi'i, M. M. O., Zain, A. D. M., Jusoh, W. H. W., \& Akib, M. M. M. (2020). The Importance of Using Augmented Reality in the Study of Kubra Al-Yaqiniyyat. International Journal of Academic Research in Business and Social Sciences, 10(11), 1268-1275.

Copyright: (c) 2020 The Author(s)

Published by Human Resource Management Academic Research Society (www.hrmars.com)

This article is published under the Creative Commons Attribution (CC BY 4.0) license. Anyone may reproduce, distribute, translate and create derivative works of this article (for both commercial and non-commercial purposes), subject to full attribution to the original publication and authors. The full terms of this license may be seen at: http://creativecommons.org/licences/by/4.0/legalcode

Vol. 10, No. 11, 2020, Pg. 1268 - 1275

Full Terms \& Conditions of access and use can be found at http://hrmars.com/index.php/pages/detail/publication-ethics 


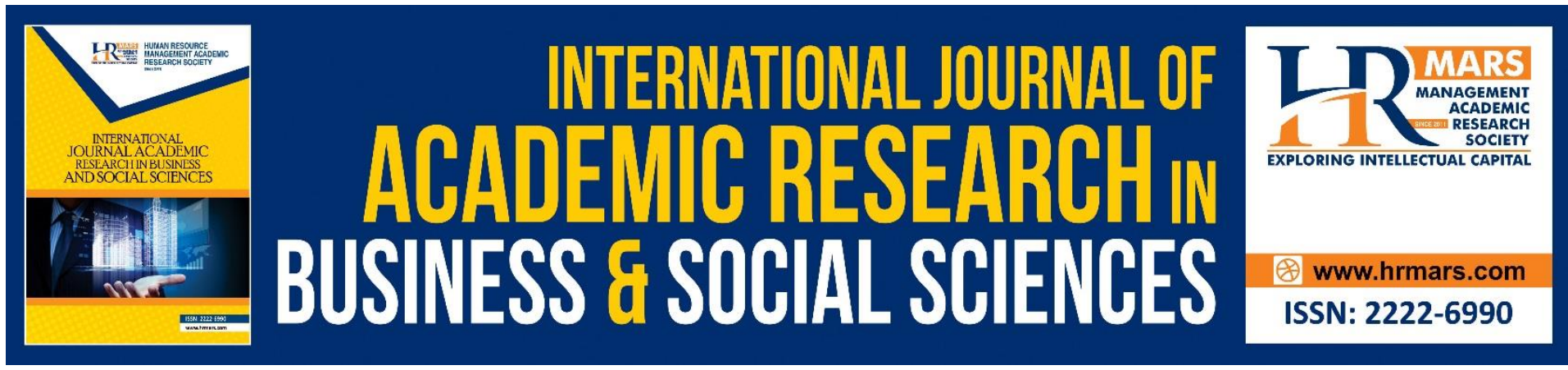

\title{
The Importance of Using Augmented Reality in the Study of Kubra Al-Yaqiniyyat
}

\author{
Mohd Hasrul Shuhari, Mohammed Muneer'deen Olodo Al- \\ Shafi'i, Aman Daima Md. Zain, Wan Hishamudin Wan Jusoh \& \\ Mohd Manawi Mohd Akib \\ Faculty of Islamic Contemporary Studies (FKI), University of Sultan Zainal Abidin (UniSZA), \\ Gong Badak Campus, 21300 Kuala Nerus, Terengganu, Malaysia, The National University of \\ Malaysia (UKM), 43600 UKM, Bangi Selangor, Malaysia. \\ Email: hasrulshuhari@unisza.edu.my
}

\begin{abstract}
Kubra al-Yaqiniyyat is the work of a contemporary scholar from Syria named Muhammad Sa'id Ramadan al-Buti where he discusses Islamic faith. This study emphasizes on the importance of using augmented reality (AR) technology in determining students' understanding of the debate in this book. The use of AR in this study is a utilization of the benefits of the latest technologies to be applied in Islamic studies, which are still relatively new and are not yet widely used. The methodology used is qualitative, using a library research method that uses documentation techniques for appropriate reference. This study concludes that, the use of current technologies such as augmented reality applications is very important for students in understanding Kubra al-Yaqiniyyat.
\end{abstract}

Keywords: Augmented Reality, Technology, Sa'id Ramadan Al-Buti, Kubra Al-Yaqiniyyat, Education.

\section{Introduction}

Education is a necessity for every Muslims. This is important when it comes to the understanding of the religion itself (Khairuldin et al., 2020). Education is the trusts and responsibility which refer to the ethical character of man that must be practiced daily, especially by every Muslim (Shuhari et al., 2019). It is also about integrity related to the nature of trust, honesty, faith, strong belief, strong morals and noble morals (Shuhari et al., 2019). In addition, it is also very close to the concept of ethics that it refers to; first, referring to knowledge of moral or moral principles, secondly, referring to the principle of moral (akhlaq) or moral values that became a guidance towards an individual or a group such as association, occupation and others (Shuhari et al., 2019; Sarri et al., 2013). Therefore, education is important because it is trust, ethics, integrity and so on, especially when it comes to the topic of faith in Islam.

Character education is based on the nusus (Quran and Sunnah), which is to create awareness that educators and their students are able to build their special characters during their life 
(Shuhari et al, 2019). Buiding a good character is an important step in becoming a role model for others (Al-Shafi'l et al., 2019). Comprehensive Islamic education includes the creed, sharia and morality. It is important to shape one's character through the positive religious values that are applied (Shuhari et al., 2020). Among the things that should be considered in faith education is an understanding of the attributes of God. For example, all scholars unanimously agree that Allah s.w.t is completely different from all beings in every aspect [Basri, Shuhari, \& Zin, 2019]. This understanding is important as the stronghold of the faith of ASWJ from false teachings (Shuhari et al., 2020). To understand this, the book of Kubra al-Yaqiniyyat explains it very well.

Allah has honoured the Muslims by making it the best of all nations and sending the Prophet Muhammad (peace be upon him) the revelation (al-wahyu) to all beings to liberate them from the darkness of shirk to the light of tawhid (Shuhari et al, 2020; Al-Shafi'I et al, 2020). The creed is a firm grip that is not easily disturbed by any doubt. The clear evidence on the explanation of faith in the Quran and Sunnah indicates that Islam strongly emphasizes the faith. The main thing that Islam requires of its followers is to justify the existence of Allah, the Almighty, and the veracity of Prophet Muhammad (peace be upon him) by professing kalimah al-Shahadah. Profession of shahadah is an important element of the Islamic faith. It signifies that there is no god worthy of true worship except Allah, and that Prophet Muhammad (peace be upon him) is the messenger of Allah. It also leads to faith in the truth of the Quran and other revealed scriptures, the apostles, the angels, and the Hereafter (Sabiruddin, 2012).

The sources used by Ahl al-Sunnah wa al-Jama'ah (ASWJ) to emphasize matters of faith are the Quran, al-Sunnah, ljmak and the intellect ('aql). The Quran and al-Sunnah are the two major sources of reference for Muslims. This is based on the instructions in the Quran that Muslims should refer to Allah and the Messenger of Allah, Muhammad (peace be upon him). References to al-Sunnah in matters of faith are based on the reliability of their beliefs, not on weak hadiths. While the reliance on sources of ijmak is only limited to ijmak members of alHaqq as in the abstraction of the nature of the attributes of Allah based on the qat i ijmak. In addition, ASWJ accepts the mind as a manhaj in the creation of faith based on the Quran which encourages Muslims to constantly think about the signs of Allah's existence and His greatness for man to reach the enlightenment (Hamat, 2008).

Therefore, Muslims should refer to authority of sources in matters of faith in line with ASWJ. As recommended by the official website of Mufti for Federal Territory in Malaysia,the main references in matters of faith are al-Fiqh al-Akbar and lectures by Mulla 'Ali al-Qari, Jawharah al-Tawhid, 'Aqidah al-'Awwam, Maqalat al-Islamiyyin wa ikhtilaf al-Musallin, alLuma' fi radd 'ala ahl al-Zaygh wa al-Bida', al-Ibanah 'an usul al-Diyanah, Istihsan al-Khaud fi 'ilm al-Kalam, al-I'tiqad wa al-Hidayah ila sabil al-Rashad, al-Asma' wa al-Sifat, Qawa'id al'Aqa'id, Ightinam al-Fawa'id fi sharh qawa'id al-'Aqa'id, al-Farq bayna al-Firaq, al-lqtisad fi alI'tiqad, Faisal al-Tafriqah bayna al-Islam wa al-Zandaqah, Iljam al-'Awwam 'an 'ilm al-Kalam, Kitab al-Mawaqif fi 'ilm al-Tauhid, al-'Aqa'id al-Nasafiyyah, al-Milal wa al-Nihal, Al-Fisal fi alMilal wa ahwa' al-Nihal, Kubra al-Yaqiniyyat al-Kauniyyah, al-'Aqidah al-Islamiyyah wa ususuha, Tabsit al-'Aqa'id al-Islamiyyah, and Tarikh mazahib al-Islamiyyah. Based on recommendations from religious authorities, particularly in Malaysia, Kubra al-Yaqiniyyat is an important reference in the field of faith. 


\section{Kubra Al-Yaqiniyyat and Ramadan Al-Buti}

The Book, Kubra al-Yaqiniyyat or its full title Kubra al-Yaqiniyyat al-Kawniyyat wujud al-Khaliq wa wazifah al-Makhluq (The greatest cosmological certainties, the existence of a Creator and the role of the Creature), is the work of a contemporary Syrian scholar, Sheikh Prof. Dr. Muhammad Sa'id Ramadan al-Buti. He was born in 1929 in Jilka, which is part of the Butan Island area (also known as Ibn 'Umar Island). It is located between the borders of Turky and the north of Iraq. He moved to Damascus with his father, Mulla Ramadan, in 1933, at the age of four. He completed his secondary education at Ma'had al-Tawjih al-Islami in Damascus. Later, at the age of twenty-four, he continued his studies at the Shariah Faculty of the al-Azhar University in 1953. He obtained his certificate of study in 1955, at the age of twenty-six. At the same university, he pursued his further studies at the Faculty of Arabic where he obtained Diploma of Education in 1956 at the age of twenty-seven (Shuhari, 2008).

At the age of thirty-one, he was appointed as Dean of the Faculty of Shariah, Damascus University in 1960. He then pursued his doctoral studies specializing in Usul al-Shari'ah alIslamiyyah at al-Azhar University. He completed his studies on 5th Rajab 1485AH, equivalent to October 30, 1965CE, at the age of thirty-six. His PhD thesis was titled 'Dawabit al-Maslahah fi al-Shari'ah al-Islamiyyah' (Al-Buti, 1966). He previously served as Head of the Department of Religion and Religious Affairs at Damascus University. His experience clearly demonstrates his greatness in the fields of knowledge. He is also recognized as a well-known scholar and has the authority to serve as a reference in areas related to Islamic science, especially in the field of 'aqeedah. He has written works in many fields and his works have been translated into many languages, such as, English, German, French, besides Arabic (Shuhari, 2008). He died while teaching in Jami' al-Iman, Damascus Syria in a bomb attack.

Kubra al-Yaqiniyyat is being used as a main reference book for the subjects USI 10102 Mabahith al-Ilahiyyat, USI 10202 Mabahith al-Nubuwwah wa al-Kawniyyat and USI 30903 Mabahith al-Sam'iyyat. Mabahith al-Ilahiyyat and Mabahith al-Nubuwwah are two Core Courses of Islamic Studies at the Faculty of Contemporary Islamic Studies (FKI), Sultan Zainal Abidin University (UniSZA), Malaysia. Meanwhile, Mabahith al-Sam'iyyat is a Program Course for the Usuluddin Studies Center at FKI, UniSZA (Graduate Guide, 2017). Based on the interview conducted with Associate Professor Dr. Mohd Fauzi Hamat (21 July 2016), a University of Malaya academic and Islamic scholar and panel of theology for Islamic Religious Affairs in Selangor (JAIS), Malaysia, Kubra al-Yaqiniyyat is a difficult book to master because of its high linguistic level. Therefore, efforts should be made to facilitate it for the benefit of students.

Selection of this book for reference and study is in line with the recommendation of Ghazali (2019). He states that due to the fact that Muslims in Malaysia hold ASWJ in high esteem, it is appropriate that books such as Kubra al-Yaqiniyyat be used as a reference for teaching 'aqeedah. This view is also in line with the study of Rahman and Idris (2018) who state that the narrative of Al-Buti's thinking can be seen in line with many of the scholars of ASWJ even in the more creative and contemporary contexts when he addressed the question of faith in the book of Kubra al-Yaqiniyyat. According to him, this work can be an important guide for Muslims in facing the challenges of modern life. Although Al-Buti's influence is significant to Muslims in Malaysia, studies on his thinking are still limited. Therefore, to 
celebrate the views of these two researchers, this study is very important to be done in order to make a scientific contribution to education especially in the field of 'aqeedah.

\section{Technology of Augmented Reality (AR) and Kubra Al-Yaqiniyyat}

Based on the reviewed literature, the study of Augmented Realitiy's application of the aspects of the use of Kubra al-Yaqiniyyat book has not been done. According to Haryani and Triyono (2017), the use of information technology (IT) has undergone rapid development. Recently, the latest technology to be introduced in the transmission of information is augmented reality (AR) technology. With this technology, users can visualize objects in 3 dimensions. AR has the advantages of being interactive and real time so many ARs are implemented in a variety of fields. In other words, AR technology combines real and virtual objects in real environments, aligns real and virtual objects with one another and runs interactively in three dimensions (3D), and in real time (Krevelen \& Poelman, 2010).

The current use of AR technology has expanded into many aspects of an individual's life and its development is very significant. This is because, the use of AR technology is very interesting and makes it easy to use in any case (Rifa'i, Listyorini \& Latubessy, 2014). The use of AR technology innovations in learning is expected to create an effective learning environment. AR is applied in education as it combines real-world situations and virtual objects that can solve problems in understanding the lessons presented (Wardani, 2015). This AR technology is also closely linked to smartphones that are so synonymous with every individual community today where people can quickly and easily access information. By using AR technology through a smartphone, it will provide information about something interesting and unique (Santoso, 2015).

This learning is categorized as a communicative approach through augmented reality technology. This is a student-centered learning that helps them actively learn to acquire knowledge, skills and attitudes (Mantasia \& Jaya, 2016). In communication, the language aspect is also important. Human beings are thus able to use language to speak, write and communicate (Zakaria, 2020). As already explained, its high linguistic level have called for researchers to provide a modern technology application that enables the reader to understand the book. This effort is also based on the problems of students to understand the book. Meanwhile, the use of this book for the three main subjects of 'aqeedah is prevallent among majority of FKI students. In addition, modern technology that is thought to help these students is augmented reality (AR) technology.

Among the benefits of having this kind of technology in education is that it helps to better educate the Sunnah of the Messenger of Allah and it can spread quickly. The Messenger of Allah (peace be upon him) also applied various latest methods aimed at facilitating knowledge to Muslims at that time. He was communicating with his companions based on their intellect. He also interacted with them according to the circumstances. Researchers like Hassan et. al (2016) suggests that technology application developers can increase Sunnah education-related applications. Thus, this technology is seen as one that can be used to explain one of the Sunnahs, particularly in introducing and teaching creeds through the book of Kubra al-Yaqiniyyat. 
The education system has undergone a major evolution in education technology with the introduction of mobile concept learning or Mobile Learning. The goal is to improve the level of learning and teaching. This learning is further enhanced by the availability of Androidbased smartphones that are easy to use and accessible to students who can get variety of free Android applications. One of the advantages is that it can enhance students' interest and motivation in the learning process (Yusoff \& Romli, 2018). Significance of the use of this technology can be seen when there are four billion mobile phones used today compared to the world's population of almost seven billion. This represents about $70 \%$ of the world's population. They are exposed to the "App" which is a short term "mobile application" that is developed for delivery and serves a variety of purposes such as entertainment, referral, business, and learning (Aminuddin, Rahman \& Yew, 2015). Therefore, in order to take advantage of this technology, this invention is very significant as it applies highly relevant smartphone technology for access to apps and AR.

The use of $A R$ in education is an important topic of research. Research on the application of AR in education is still in its infancy, and there is lack of research on the effects and implications of AR in education (Khan, Johnston \& Ophoff, 2019). In the Malaysian context, this concept is still at an early stage in the process of learning in education centers (Yusoff \& Romli, 2018). In Islamic studies, this technology is still poorly applied, among the applications that have been developed in Islamic studies is the Daily Prayer AR in Malaysia (Khairuldin et al, 2019). Based on previous research, there has been no study on the creed in general, and on Kubra al-Yaqiniyyat, using AR technology.

Therefore, to further enhance the existence of Islamic scientific applications, especially in the field of creed learning, AR applications and their effectiveness studies need to be implemented immediately so that Islamic faith education is not left behind in utilizing modern technology. It is also in line with the Sunnah of the Messenger of Allah (peace be upon him) which signifies the importance of preaching and teaching using current methods and based on the suitability of the target group. It is expected to benefit students especially those who use Kubra al-Yaqiniyyat in USI 10102 Mabahith al-Ilahiyyat, USI 10202 Mabahith al-Nubuwwah wa al-Kawniyyat and USI 30903 Mabahith al-Sam'iyyat. This application can also be used by academics and the public who are interested in the book and its author, Sheikh Prof. Dr. Muhammad Sa'id Ramadan al-Buti.

\section{Conclusion}

The use of augmented reality technology in the study of Kubra al-Yaqiniyyat is crucial. It is based on reality now that many of our younger generation, especially the students, now use smartphones. This makes it easier for them to use augmented reality app. Therefore, this technology needs to be used by educators to give the younger generations the understanding of Islamic creed, especially the book, Kubra al-Yaqiniyyat.

\section{Acknowledgement}

This paper is founded on the research project of the Scholarship of Teaching and Learning (SoTL), Project Code: UniSZA / 2019 /SoTL / 01. Special appreciation is owed to Sultan Zainal Abidin University (UniSZA), Centre for Management of Academic Excellence and Innovation (COMAE-i) UniSZA and Center for Research Excellence \& Incubation Management (CREIM) UniSZA for sponsoring and supporting this research. 


\section{Corresponding Author}

Mohd Hasrul Shuhari

Centre for Usuluddin Studies, Faculty of Islamic Contemporary Studies (FKI), University of Sultan Zainal Abidin (UniSZA), Gong Badak Campus, 21300 Kuala Nerus, Terengganu, Malaysia.

Email: hasrulshuhari@unisza.edu.my

\section{References}

Al-Buti, M. S. R. (1966). Dawabit al-maslahah fi al-shari'ah al-islamiyyah, Damascus: alMaktabah al-Umawiyyah.

Aminuddin, H., Rahman, F., \& Yew, S. K. (2015). Explore logical thinking through the use of mobile applications (Meneroka pemikiran logik melalui penggunaan aplikasi mudah alih), International Journal Of Education And Training (Injet), 1(2), pp. 1-7, November 2015.

Hamat, M. F. (2008). The challenge of strengthening the faith in malaysia: focusing on aspects of the teaching approach (Cabaran pengukuhan akidah di malaysia: tumpuan aspek pendekatan pengajaran). Jurnal Penyelidikan Islam, Vol. 21, pp. 13-32.

Hamat, M. F. (2016). Interview in the meeting room of the university of Islamic studies sultan zainal abidin, gong badak campus, terengganu, 21 July 2016.

Haryani, P., and Triyono, J. (2017). Augmented reality (ar) as an interactive technology in the introduction of cultural objects to society (Augmented reality (ar) sebagai teknologi interaktif dalam pengenalan benda cagar budaya kepada masyarakat), Jurnal SIMETRIS, Vol. 8 No. 2, pp. 807-812.

Khan, T., Johnston, K., and Ophoff, J. (2019). The impact of an augmented reality application on learning motivation of students. Advances in Human-Computer Interaction, Volume 2019 (2), pp. 1-14.

Mantasia \& Jaya, H. (2016). Development of augmented reality technology as a reinforcement and support of learning methods in smk for 2013 curriculum implementation (Pengembangan teknologi augmented reality sebagai penguatan dan penunjang metode pembelajaran di smk untuk implementasi kurikulum 2013). Jurnal Pendidikan Vokasi, Volume 6, No 3, pp. 281-291, November 2016.

Yusoff, A. F., \& Romli, A. B. (2018). Use of mobile apps for Islamic science, technology and engineering courses ( $m$-istech) in polytechnic malaysia (Kebolehgunaan aplikasi mudah alih (mobile apps) bagi kursus sains, teknologi dan kejuruteraan dalam Islam (m-istech) di politeknik malaysia), Attarbawiy: Malaysian Online Journal Of Education, Vol. 2, No. 1 pp. 18-28.

Rahman, A. M. A. A. A., and Idris, M. R. (2018). Ramadan al-buti, his life history and some aspects of his contribution (Ramadhan al-buti, riwayat hidup dan beberapa aspek sumbangan pemikirannya). At-Tahkim, Vol. 8, No. 23, pp. 1-6.

Rifa'i, M., Listyorini, T., and Latubessy, A. (2014). The application of augmented reality technology to android-based home catalog applications (Penerapan teknologi augmented reality pada aplikasi katalog rumah berbasis android), in Prosiding SNATIF Ke-1 Tahun 2014. Fakultas Teknik Universitas Muria Kudus, pp. 267-274.

Sabiruddin. (2012). Faith is the basis for human perfection (Akidah asas kesempurnaan insan). Jurnal al-Hikmah, Vol. 4, pp. 106-110.

Santoso, D. (2015). Design an augmented reality application to show the writing process of batik (Rancang bangun aplikasi augmented reality untuk menampilkan proses 
pembuatan batik tulis). M.S. thesis, Program Studi Informatika, Universitas Muhammadiyah Surakarta.

Sarri, C., Valkanos, E., Panda, D., \& Panitsides, E. A. (2013). Factors affecting participation in Vocational Education and Training: The case of Vocational Training Institutes in Greece. Multilingual Academic Journal of Education and Social Sciences, 1(2), 76-90.

Shuhari, M. H. (2008). Al-Buti thought: conclusions on the concepts of al-hidayah and al-idlal (Pemikiran al-buti: kupasan terhadap konsep al-hidayah dan al-idlal), Degree Project Paper, Academy of Islamic Studies, University of Malaya.

Shuhari, M. H., Hamat, M. F., Basri, H., Khairuldin, W. M. N., W. M. K. F., Wahab, M. R., Engku Alwi, E. A. Z., and Mamat, A. (2019). Concept of al-amanah (trustworthiness) and almas'uliyyah (responsibility) for human's character from ethical islamic perspective, Journal of Legal, Ethical and Regulatory Issues, 22(S1), pp. 1-5.

Shuhari, M. H., Hamat, M. F., Al-Shafi'i, O. M. M., Jusoh, W. H., Zin, M. S. A., and Wahab, M. R. (2019). The concept of integrity for muslim's character based on al-ghazali's ethical perspective, Journal Of Legal, Ethical And Regulatory Issues, 22(S1), pp. 1-5.

Shuhari, M. H., Basri, H. M. N., Yazid, M. N. S., Yusoff, M. S. H., Yahya, N., and Akib, M. M. (2020). The credibility of imam al-shafi'i in his journey for finding scientific knowledge, International Journal of Advanced Science and Technology, Vol. 29, No. 5, pp. 1313113139.

Shuhari, M. H., Ismail, M. S., Ali, M. S., Al-Shafi'I, M. M. O., and Akib, M. M. (2020). The importance of using current technology in the study of islamic ethics, International Journal of Advanced Trends in Computer Science and Engineering, 9(3), pp. 3945-3949, May-June 2020.

Hassan, S. N., Zakaria, N., Long, M. Y., Goje, K., and Said, M. W. (2016). The development of technology applications in the teaching and learning of Hadith in the age of globalization (Pembangunan aplikasi teknologi dalam memantapkan pengajaran dan pembelajaran hadis pada zaman globalisasi), in Seminar Warisan Nabawi (SWAN 2016), At-Fatoni University, Thailand, Vol. 5, pp. 1-10.

Van Krevelen, D. W. F., and Poelman, R. (2010). A survey of augmented reality technologies, applications and limitations. The International Journal of Virtual Reality, 2010, 9 (2), pp. 1-20.

Khairuldin, W. M. K. F.W., Embong, A. H., Anas, W. N. I. W. N., Ismail, D., and Mokhtar, W. K. A. W. (2019). An augmented reality (ar) approach in educational integration of du'a in Islam. International Journal Of Academic Research In Progressive Education And Development, 8(1), pp. 32-39.

Khairuldin, W. M. K. F.W., Wan Nor Anas, W. N. I., Embong, A. H., Hassan, A., and Imas, M. M. (2020). Islamic gamification: application of gamification concepts in Islamic education according to Islamic perspective, TEST Engineering \& Management, Volume 83, pp. 10885-10890.

Wardani, S. (2015). The use of augmented reality (ar) technology for the introduction of java characters for children (Pemanfaatan teknologi augmented reality (ar) untuk pengenalan aksara jawa pada anak). Jurnal Teknologi, Vol. 8, No. 2, pp. 104-111.

Zakaria, R., Ismail, M. S., Md Zain, A. D., Shuhari, M. H., Wahab, M. R., Syed Omar, S. H., Ali, M. S., and Engku Alwi, E. A. Z. (2020). Relationship effect of demographic factors on selfefficacy of arabic language proficiency. Journal of Critical Reviews, Vol 7,Issue 7, pp. 468-472. 